\title{
Developing the scale on discipline expectations of students: A validity and reliability study
}

\author{
Gülsen Özcan', Işıl Aktă̆ ${ }^{2}$, Kaine Gülözer ${ }^{3}$ \\ ${ }^{1,2}$ Department of Physical and Sport Education, Bolu Abant İzzet Baysal University, Turkey \\ ${ }^{3}$ Department of English Language Teaching, Bartin University, Turkey
}

\section{Article Info \\ Article history: \\ Received Mar 13, 2020 \\ Revised Aug 18, 2020 \\ Accepted Oct 12, 2020}

\section{Keywords:}

Discipline

Expectation

Reliability

Scale

Student

Validity

\begin{abstract}
The study aimed to develop a valid and reliable scale to measure the expectations of students from the discipline program implemented in their schools. The study was conducted with students studying in seven different high schools in fall semester of 2019-2020 school year. As a result of the Confirmatory Factor Analysis (CFA), a 5-point Likert scale with 3 dimensions and 22 items was established. It was revealed that the fit index values for the final form of the scale are $\chi^{2}=360.92$, $\mathrm{df}=206, \mathrm{P}=0.00$, RMSEA $=0.062$, GFI $=0.86$, AGFI $=0.82$, CFI $=0.93$, MR $=0.063$; $\mathrm{NNFI}=0.92$. Cronbach Alpha reliability test was used to test the reliability of the ultimate scale and test retest reliability value was used to measure the stability of the test. Reliability value for the whole test was determined as .823 , for the factor of Effective Teaching Discipline Expectation as 717, for the factor of Behavioral Discipline Expectation as 596, and for the factor of Social Discipline Expectation as .636. Test retest reliability of the test was determined as .763. Upon the evaluation of the analyses made, it was concluded that scale on discipline expectations of students is a valid and reliable scale to measure the discipline expectations of the students studying in secondary education institutions in Turkey.
\end{abstract}

This is an open access article under the CC BY-SA license.

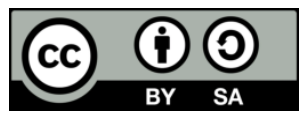

\section{Corresponding Author:}

Gülsen Özcan,

Department of Sport Sciences,

Bolu Abant İzzet Baysal University,

Gölköy Kampüsü, Spor Bilimleri Fakültesi, Bolu, Turkey.

Email: gulsenozcan@ibu.edu.tr

\section{INTRODUCTION}

School principals and teachers mostly tend to believe that discipline problems will diminish when they establish rules or a disciplinary board. However, they also know that peace never can be ensured in the school. This is somewhat related to the natural consequence of forcing people to live together. However, existence of causes is the beginning for the solution of problems. In consequence, the most appropriate quest might be the decision which measures to be taken to have fewer problems. According to the researchers who agonize over discipline in schools, there might be potential average solutions to potential misbehaviors of students. Neverthless, when it is considered that each and every student may have a quite different world, one gives away to despair. Based on the literature concerning researchers' perspectives regarding discipline in schools, models and implementation of discipline establishes theoretical infrastructure of the present study with the awareness of this restrictive reality at the beginning of the study.

The concept of discipline in practice is often expressed as the synonym for punishment due to a misbehavior $[1,2]$. Whereas, discipline and punishment should not be confused with each other. Punishment 
is the reaction to a misbehavior and disturbs the organism, but discipline includes necessary measures to prevent misbehaviors [3, 4]. Discipline means both prevention and recovery of misbehaviors. Küçükahmet [5] mentions that teachers must determine what kind of discipline they want before deciding how and to what extent they want to discipline the students. The right way of discipline for one teacher may be wrong for another. For instance, one teacher may ask the students to answer a question by standing up. For another, on the other hand, what matters would be the correctness of the answer. The main purpose of discipline in education is enabling the students to control and assess their own behaviors. Students must be aware of their behaviors whether in the class or in the community and decide if they are appropriate or not. Teachers' task should be having the students comprehend these behaviors in the best way. Children internalize the values and rules which are for the benefit of themselves and those around in consequence of effective disciplinary methods [6].

When the disciplinary models that form the basis for the implementation of discipline in schools are checked on, we see that there are various classifications. Sarıtaş [1] states six discipline models regarding classroom management: 1-Canter's Model (Assertive Discipline Model), 2- Glasser's Model (ProblemSolving Model with Reality Therapy), 3- Kounin's Model (Instructional Management Theory), 4-Behaviorist Model, 5- Teacher Effectiveness Training Model, 6- Rational Consequences Model. Tertemiz [3] on the other hand, emphasises on Social Discipline Model of Rudolf Dreikurs. Celep [7] classifies discipline models as Assertive Behavior Model, Classroom Management Based on Responsibility and Analysis of Interpersonal Relationships Model, and [8-17] assert Preventive Discipline, Social, Carter, Glasser and Gordon Model.

When the literature regarding discipline in school is reviewed, to the researchers' knowledge, no study to reflect the expectations of students was found. In addition, some previous studies conducted in Turkey and other countries considered to be helpful to the theoretical infrastructure of the present study and scale development process are as follows: Preferences of Teacher Candidates regarding Discipline Models in Classroom [18], Investigation of Primary School Teachers' Perception of Discipline Types They Use for Classroom Management [19], Validity and Reliability Analysis of the Scale on Discipline Strategies in Physical Education for Turkish Students [20], Discipline Models of Ideal Teacher Candidates [21], The Relationship between Teachers and Trust of the Students and Classroom Discipline Beliefs [22], Discipline Problems Encountered by Class Teachers [23], The Relationship between Personality Traits of Teachers in Public High Schools and Their Discipline Styles [24], Developing School Discipline Implementations [25],Opinions of Teacher Candidates on Determination and Application of Classroom Rules [26], Opinions of Primary School Class Teachers on Discipline in Classroom [27], iscipline Models used by Primary School Class Teachers [28], The Impact of Discipline Models used by Primary School Class Teachers on Students [29], Discipline Models used by Teachers in Primary and Secondary Schools [30], Discipline Problems in Public High Schools and Approaches of Related Groups (Teachers, Students, Principals, Parents) [31], Approaches on which Classroom Management and Discipline Models are Based [10], Classroom Discipline and Students' Responsibility [32], Effective Discipline Scale Reflecting the Belief of Teachers regarding Discipline of Students [33].

Given the analysis of the above studies, it reveals that the researchers of discipline in schools are mostly curious about perceptions, opinions and suggestions of teacher candidates, teachers and students regarding discipline. However, it may seem more plausible to recognize the students who are the main figure of discipline problem. How do the students perceive disciplinary implementations that researches have such a high opinion of? To what extent the disciplinary expectations of the students would well-suit with these studies? The Scale on Discipline Expectations of Students (SDES) developed to find answers to these questions is, in a way, the crosscheck of the literature and it aims to remind the expectations of students, the main stakeholders of schools to educators.

\section{RESEARCH METHOD}

\subsection{Participants}

The study was conducted with three different study groups. The study groups and the tests given to the study groups are presented in Table 1. As seen in Table 1, the preliminary test form of the scale development study was applied to a total of 477 students; 180 females (37.7\%) and 297 males (62.3\%) studying in 7 different schools. 25 items that remained in the scale after EFA were applied to a total of 196 students, 70 females $(35.7 \%)$ and 126 males (64.3\%) studying in two different high schools. In order to measure the test-retest reliability of the scale, 22 items in the ultimate test were applied to a total of 42 students, 18 females (42.8\%) and 24 males (57.2\%) studying in the same high school. 


\begin{tabular}{cccccc}
\multicolumn{5}{c}{ Table 1. The distributions of the participants } \\
\hline Study group & Type of implementation & $\begin{array}{c}\text { The } \\
\text { schools }\end{array}$ & $\begin{array}{c}\text { Female } \\
(\mathrm{n}, \%)\end{array}$ & $\begin{array}{c}\text { Male } \\
(\mathrm{n}, \%)\end{array}$ & $\begin{array}{c}\text { Total number } \\
\text { of students }\end{array}$ \\
\hline Study Group I & Draft SDES Form & $\begin{array}{c}7 \text { High } \\
\text { Schools } \\
\text { Study Group II }\end{array}$ & $180(37.7)$ & $297(62.3)$ \\
Study Group III & Confirmatory Factor Analysis for SDES & $\begin{array}{c}\text { Schools } \\
1 \text { High } \\
\text { School }\end{array}$ & 18 (42.8) & $24(57.2)$ & 196 \\
\hline
\end{tabular}

\subsection{Findings regarding exploratory factor analysis (EFA)}

In the present study, it was planned to develop a valid and reliable scale to measure the discipline expectations of students. Thus, primarily an EFA test was needed to provide information regarding the validity of the draft scale composed of 30 items. The EFA test was performed on the data collected from 477 students studying in seven different high schools. EFA is a statistical technique aiming at gathering variables that measure the same structure or quality together and explaining measurement with a few factors $[34,35]$. Factor analysis is also defined as the process of revealing new concepts (variables) called factorization or common factors or obtaining functional definitions of concepts by using the factor loads of the factors. Factor analysis may not be suitable for all data structures [36,37]. Suitability of the data for factor analysis can be examined with Kaiser-Meyer-Olkin (KMO) coefficient and the Barlett's test for sphericity. The KMO coefficient gives information about whether the data matrix is suitable for factor analysis or not. KMO should be higher than 60 [38], In reference to this information it is seen that KMO value of the study was .811 and Bartlett's value was. 435. According to this result, it was concluded that the sample size was sufficient for EFA. According to Kurnaz and Yiğit [39], the sample size should be ten times the observed variable. Also, when the results of Bartlett's test for sphericity are examined, it is seen that the Chi-Square $(\chi 2)$ value was significant $\chi 2=3270,286 ; \mathrm{p}<0.01)$, accordingly, it is assumed that the data come from a multivariate normal distribution [40].

In an attempt to reveal the factor pattern of SDES, Principal Components Analysis was selected as factorization method and Vertical Rotation method was selected as rotation method in the form of Maximum Variance (Varimax). As a result of the analysis, it was seen that there were three components with an eigenvalue above 1 for 30 items taken as the basis of the analysis. Contribution of these components to total variance was found as $34.376 \%$. In the analysis repeated for three factors, the effect of the first factor on total variance was found as $14.077 \%$, of the second factor as $11.743 \%$ and of the third factor as $8.555 \%$. Another decision to be made about scale items in EFA is related to load values of the items. According to Çokluk; Şekercioğlu; and Büyüköztürk [40], the lower limit for load values of the items must be 32 and the difference between the loads values of the items should be over .1; in other words, the items should not overlap. In reference to this information a total of five items, load values of which were close for both factors and load values of which were under 32 (items 6, 7, 22, 23, 25) were removed from SDES. Before naming the threefactor structure formed in the scale after EFA, the theoretical structure forming the basis for development of the scale was reviewed, the items grouped under the factors are interpreted one-by-one and named in conformity with the factors. Thus, the items grouped in factor one were named as Effective Teaching Discipline Expectation, those in factor two were named as Behavioral Discipline Expectation and those in factor three were named as Social Discipline Expectation.Total item variances of SDES, load values after rotation are given in Table 2. 
Table 2. Transformed principal components factor analysis for the scale on discipline expectations

\begin{tabular}{|c|c|c|c|}
\hline & Items & $\begin{array}{c}\text { Factor common } \\
\text { variance }\end{array}$ & $\begin{array}{c}\text { Factor } \\
\text { load }\end{array}$ \\
\hline \multirow{13}{*}{$\begin{array}{l}\text { Effective teaching } \\
\text { discipline expectation } \\
\text { (factor-1) }\end{array}$} & $\begin{array}{l}\text { Teachers should clearly express their expectations and feelings in } \\
\text { order to maintain discipline in the classroom. }\end{array}$ & 0.281 & 0.507 \\
\hline & $\begin{array}{l}\text { Classroom rules should be exhibited in the classroom to prevent } \\
\text { discipline problems. }\end{array}$ & 0.272 & 0.497 \\
\hline & Teachers should apply the discipline rules consistently. & 0.423 & 0.629 \\
\hline & $\begin{array}{l}\text { All employees in the school should act in unison in respect of } \\
\text { discipline rules. }\end{array}$ & 0.464 & 0.531 \\
\hline & Teachers should solve discipline problems with a humane approach. & 0.464 & 0.639 \\
\hline & Teachers should solve discipline problems by giving advices. & 0.336 & 0.554 \\
\hline & $\begin{array}{l}\text { Teachers should also hold themselves responsible for discipline } \\
\text { problems. }\end{array}$ & 0.312 & 0.558 \\
\hline & $\begin{array}{l}\text { Teachers should have a good command of their fields to solve } \\
\text { discipline problems. }\end{array}$ & 0.357 & 0.592 \\
\hline & $\begin{array}{l}\text { Teachers should use different tools in the classroom to avoid discipline } \\
\text { problems. }\end{array}$ & 0.323 & 0.527 \\
\hline & $\begin{array}{l}\text { It should be believed that any student with disciplinary problems can } \\
\text { also act positively. }\end{array}$ & 0.335 & 0.530 \\
\hline & Students who have discipline problems should be treated patiently. & 0.283 & 0.527 \\
\hline & $\begin{array}{l}\text { The students who create disciplinary problems should be made to feel } \\
\text { valued. }\end{array}$ & 0.274 & 0.455 \\
\hline & $\begin{array}{l}\text { It should be accepted that discipline problems are not caused by a } \\
\text { single person or there might not be a single reason. }\end{array}$ & 0.237 & 0.456 \\
\hline \multirow{6}{*}{$\begin{array}{l}\text { Behavioral discipline } \\
\text { expectation (factor-2) }\end{array}$} & $\begin{array}{l}\text { Students should be aware of the punishments for all discipline } \\
\text { problems. }\end{array}$ & 0.292 & 0.511 \\
\hline & Students should be aware of the rewards for positive behaviors. & 0.301 & 0.533 \\
\hline & Students should be awarded for their positive behaviors. & 0.150 & 0.354 \\
\hline & $\begin{array}{l}\text { Responsibility should be assigned to students to prevent discipline } \\
\text { problems. }\end{array}$ & 0.205 & 0.392 \\
\hline & Students should be convinced why they should act positively. & 0.350 & 0.553 \\
\hline & $\begin{array}{l}\text { Students should be given a chance to solve their own discipline } \\
\text { problems. }\end{array}$ & 0.405 & 0.558 \\
\hline \multirow{3}{*}{$\begin{array}{c}\text { Social discipline } \\
\text { expectation (factor-3) }\end{array}$} & $\begin{array}{l}\text { Students causing discipline problems should not be alienated in the } \\
\text { school. }\end{array}$ & 0.510 & 0.691 \\
\hline & $\begin{array}{l}\text { It should not be forgotten that the students causing discipline problems } \\
\text { are also members of the class. }\end{array}$ & 0.469 & 0.673 \\
\hline & $\begin{array}{l}\text { Students who cause discipline problems shot not always be treated like } \\
\text { a criminal. }\end{array}$ & 0.405 & 0.599 \\
\hline
\end{tabular}

When Table 2 is examined, it is seen that the impact of the items on common variance changes between 0.150 and 0.510 , on the other hand, load values of the items after rotation are between 0.354 and 0.691 .

\subsection{Findings related to confirmatory factor analysis (CFA)}

A total of 25 scale items obtained as a result of EFA were applied to a total of 196 high school students studying in two different high schools. CFA was performed on the data of the students. The most important difference between EFA and CFA is that any coefficient or coefficients cannot be obtained regarding the validity of the overall structure of the scale in EFA, while coefficients (fit indices) regarding the validity of the structure can be produced in CFA. Thus, the researcher may have a clearer idea regarding the overall validity of the model [40]. Accordingly, the error variances of items 3, 4 and 5 were found over 90 in CFA made by using Lisrel Program. Although $t$ and load values of these items were high, it was decided to remove 3 items from the scale in order to increase the fit indices of the scale. Thus, the ultimate form of the scale was obtained as a result of CFA. The variables and error variances of the ultimate items of SDES are shown in Figure 1.

Upon the review of the CFA results in Figure 1, it was seen that the $t$ values of the items varied between 5.89 and 9.27. Upon the review of the error variances of the observed variables of the ultimate scale obtained in CFA, it was seen that they have varied between 0.58 and 0.86 . The fit index values for the ultimate form of the scale were as follows; Chi-Square $=360.92, \mathrm{df}=206, \mathrm{P}=0.00, \mathrm{RMSEA}=0.062$, GFI $=$, $86, \mathrm{AGFI}==0.82, \mathrm{CFI}=, 93 \mathrm{RMR}=0.063 ; \mathrm{NNFI}=0.92$. 


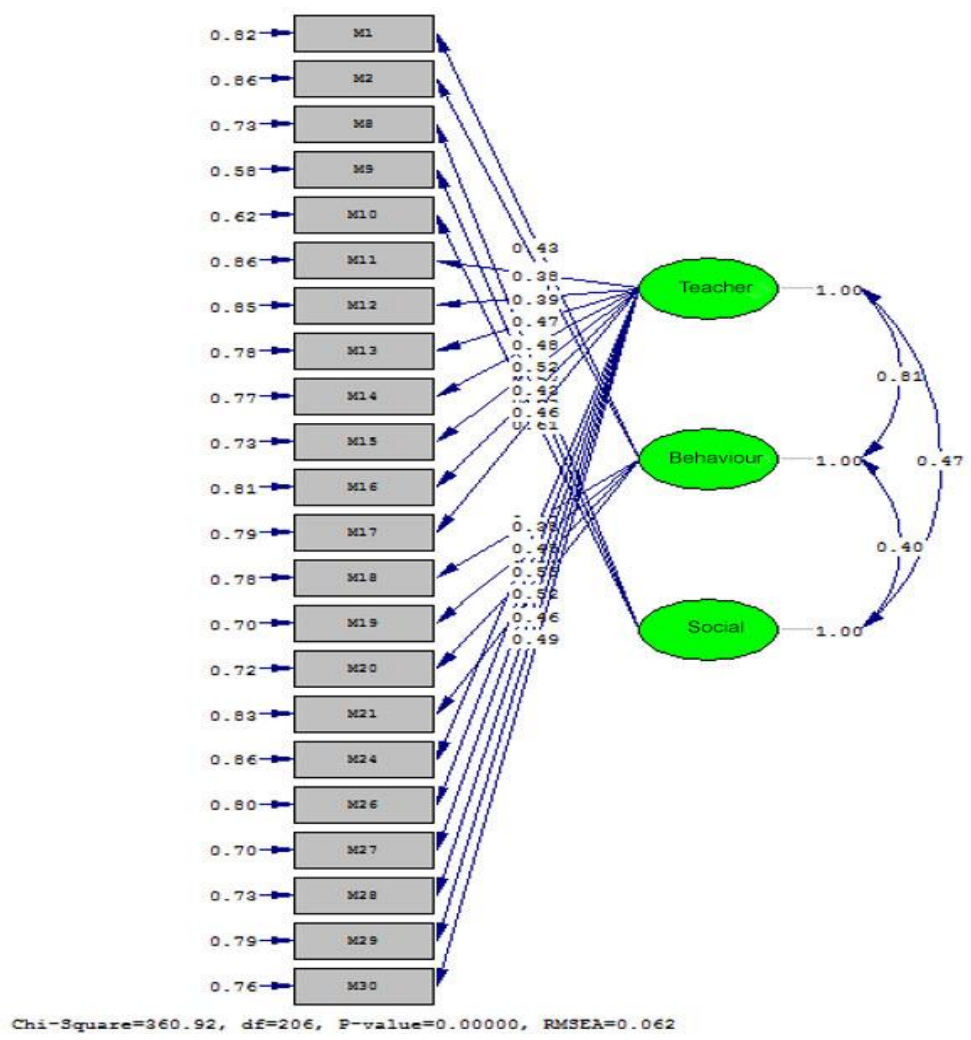

Figure 1. Results of the confirmatory factor analysis

\subsection{Reliability analysis findings of SDES}

Cronbach Alpha reliability analysis was made to obtain information regarding the internal consistency of the items in ultimate scale and test-retest reliability analysis was made to measure the stability of the test. The Cronbach Alpha reliability level of SDES in total was found as .823 , for the factor of Effective Teaching Discipline Expectation as .717, for the factor of Behavioral Discipline Expectation as .596 , and for the factor of Social Discipline Expectation as .636. Test retest reliability of the test was determined as .763.

\section{RESULTS AND DISCUSSION}

The present study was conducted to develop a valid and reliable scale to have information regarding the discipline expectations of the students. Because there is no other scale developed to match up with this scale, the data obtained from the scale were interpreted in itself. At the end of the EFA performed to determine the construct validity of the items generated on the basis of the theoretical infrastructure of the scale, the effect of three-factor items on the total variance was found as $34.376 \%$. It was decided to keep 25 items load values of which were over .32 in the draft scale. According to Thompson [41], the effect of items on common variance in general should be around .50. However, it is not possible to obtain high common variance values in social sciences most of the time. Therefore, the value of common variance determined as .40 by Costello and Osborne [42], should be a more accurate preference. Tabachnick and Fidell [43] on the other hand state that the items common variance of which are below .20 are the signals of the heterogeneity of the items [43]. According to this view, the criterion related to common factor variance should be taken as .20 [44]. On the other hand, it is suggested that the lower bound of the load values of the items should be 32 [40]. If this information related to scale development are taken as criteria, it can be said that the EFA results of SDES are at a good level in terms of the construct validity of the scale.

As a result of the CFA performed on the data collected from the implementation of 25 items generated after EFA to 196 high school students revealed that the error variances of items 3, 4 and 5 were over made by using Lisrel Program. Although $t$ and load values of these items were high, it was decided to remove these items from the scale in order to increase the fit indices of the scale. According to Çokluk, Şekercioğlu and Büyüköztürk [40], in evaluation of the results of confirmatory factor analysis, the error 
variance of the items in the scale should be lower than 90 , and $t$ values should be over 2.56 . If $t$ values are over 2.56 of the scale, it means that the scale is significant at .01 level [45]. Therefore, when the values of the ultimate scale composed of 22 items are examined, it is considered that the scale provides the construct validity. On the other hand, when the fit index values of the scale are examined, the first value to be checked is the $\mathrm{p}$ value insignificance of $\mathrm{p}$ value is desirable. Upon review of the CFA results in Figure 1, $\mathrm{p}$ value is significant at the level of 0.01. According to Kline [46]; Sümer [47], it is normal for the p value to be significant in many CFA because the sample size is large. Another fit value that needs to be considered is $\chi 2 /$ sd ratio. When these values are proportioned, it is seen that $360.92 / 206=1.752 . \chi^{2}$ If the /sd ratio is below 3 it means a perfect fit, and if it is below 5 , it means medium fit $[46,47]$. When this information is taken as the reference, it can be said that the $\chi 2 / s d$ ratio of the scale fits perfectly. The RMSEA value in the road diagram is 062. If RMSEA value is below 05, it means a perfect fit and below 08, it means a good fit [45]. If it is below .10, it means a poor fit [43]. Examination of fit indices reveals that GFI $=0.86$, AGFI $=0.82$, CFI $=.93$, standardized RMR $=0.063, \mathrm{NNFI}=0.92$. If GFI and AGFI are over .90 , it means a good fit [48]. In this context, it can be said that GFI and AGFI values are weak fits. On the other hand, CFI and NNFI values over 90 indicate a good fit [47]. Therefore, it can be said that the CFI and NNFI values of the scale indicate a good fit. It can be said that the overall fit values of the scale are within the scope of good fit values.

If the reliability analysis results of the ultimate scale are interpreted, it was determined that the total Cronbach Alpha reliability of the ultimate test was .823, for the factor of Effective Teaching Discipline Expectation as 717, for the factor of Behavioral Discipline Expectation as 596, and for the factor of Social Discipline Expectation as .636. Test retest reliability of the test was determined as763. According to Akgül \& Çevik [49], Cronbach Alpha coefficient is a measure of the consistency of the scores related to the items with the total test scores. When this coefficient is in the range of 0.60 and 0.80 , the scale is "quite reliable" and if in the range of 0.80 and 1.00 , it is "highly reliable." When this information is taken as a reference, it can be said that the reliability of SDES is satisfactory in general.

In brief, the SDES, developed to measure the discipline expectations of students, is a 5-point Likert scale composed of three factors as Effective Teaching Discipline Expectation, Behavioral Discipline Expectation and Social Discipline Expectation and 22 items. There are no negative items in the scale. Given the interpretation of the data obtained from the scale, it was concluded that SDES is a valid and reliable measuring tool.

\section{CONCLUSION}

Because attractive technological stimuli make students' lives immensely busy, it has become very difficult to have the students to participate in the classroom. This situation affects all stakeholders adversely in the learning-teaching process. However, the review of previous studies reveal that they were mostly paying attention to discipline models where teachers and principals are dominant but not to paying attention to opinions of students. With the present study, it was considered to develop a scale based on the expectations of students which would question the implementations of discipline at schools. Scale on discipline expectations of students is valid and reliable to measure the discipline expectations of the students studying in secondary education institutions in Turkey. However, the present study is limited to 477 students enrolled in high schools. Therefore, developing similar scales in future studies with larger student groups and students of different grades would contribute to school principals and teachers, particularly in terms of classroom management.

\section{REFERENCES}

[1] Sarıtaş, M. "Sınıf yönetimi ve disiplin ile ilgili kurallar geliştirme," L. Küçükahmet (Ed)., Sinıf yönetiminde yeni yaklaşımlar (4.Bask1). Ankara, Nobel Yayınları, pp. 43-8, 2005.

[2] Halis, İ., Sinif yönetimi. Konya: Ceylan Yayınları, 2001.

[3] Tertemiz, Neşe, "Sınıf yönetimi ve disiplin modelleri," L. Küçükahmet (Editör), Sinıf yönetimi. Ankara, Pegem Akademi, pp. 110-131, 2007.

[4] Erden, M., Öğretmenlik mesleğine giriş. İstanbul: Epsilon Yayınları, 2005.

[5] Küçükahmet, L., Program geliştirme ve öğretimi (20. Basım). Ankara: Nobel Yayın Dağıtım, 2007.

[6] Yavuzer, H., Çocuğu tanımak ve anlamak. İstanbul, Remzi Kitabevi, 2004.

[7] Celep, C., Sinif Yönetiminde Kuram ve Uygulama, (4. Bask1). Ankara: Pegem Akademi, 2008.

[8] Yüksel, Ö., Insan kaynaklarl yönetimi. Ankara, Gazi Kitabevi, 1998.

[9] İlgar, L., Eğitim yönetimi okul yönetimi sınıf yönetimi, (3.Basım). İstanbul: Beta Basım, 2005.

[10] Aksoy, N., "Sınıf yönetimi ve disiplin modellerinin dayandığı temel yaklaşımlar," Kuram ve Uygulamada Eğitim Yönetimi, vol. 25, pp. 9-20, 2001.

[11] Edwards, C. H., Classroom discipline \& management, (5th ed.). NJ: John Wiley \& Sons, Inc, 2008.

[12] Hardin, C. J., Effective classroom management, (2nd ed.). NJ: Pearson, 2008. 
[13] Aydın, B., "Öğretmenlerin kendi sınıf disiplin sistemleri oluşturması," Sosyal Bilimler Araştırmaları Dergisi, vol. 2, no. 1, pp. 19-32, 2006.

[14] Pala, A. "Sınıfta istenmeyen öğrenci davranışlarını önlemeye dönük disiplin modelleri,” Manas Üniversitesi Sosyal Bilimler Dergisi, vol. 13, pp. 171-179, 2005.

[15] Manning, M. L. and Bucher, K. T., Classroom management: Models, applications, and cases. Upper Saddle River, N.J: Pearson/Merrill Prentice Hall, 2007.

[16] Glasser, W., Başarısızlı̆̆ın olmadiğı okul, (1. Baskı). İstanbul: Beyaz Yayınları, 1999.

[17] Jones, V. and Jones, L., Comprehensive classroom management. Boston: Pearson, 2007.

[18] Ünsal, H., "Okulda ve sınıfta disiplin,” in M. Ç. Özdemir (Ed)., Sinıf Yönetimi, Pegem Akademi, pp. 231-263, 2017.

[19] Vatansever-Bayraktar, H. and Doğan, M.C., "Investigation of primary school teachers' perception of discipline types they use for classroom management," Higher Education Studies, vol. 7, no. 1, pp. 30-45, 2017.

[20] Pehlivan, Z., "Beden eğitiminde disiplin sağlama stratejileri ölçeğinin Türk öğrenciler için geçerlik ve güvenirlik analizi," Sport Sciences, vol. 12, no. 2, pp. 14-23, 2017.

[21] Kentli, D. F., "İdeal öğretmenlerin disiplin modelleri," Mersin Üniversitesi Eğitim Fakültesi Dergisi, vol. 12, no. 1, pp. 290-302, 2016.

[22] Arslan, Y. and Polat, S., "The relationship between teachers' trust in students and classroom discipline beliefs," International Education Studies, vol. 9, no. 12, pp. 81-89, 2016.

[23] Sadık, F. and Arslan, S., "İlkokul sınıf öğretmenlerinin disiplin problemleri ile ilgili görüşlerinin incelenmesi," Turkish Studies, vol. 10, no. 3, pp. 115-138, 2015.

[24] Uğurlu, B., "Resmi liselerde çalışan öğretmenlerin kişilik özellikleri ile kullandıkları disiplin stilleri arasındaki ilişkinin incelenmesi (Yayımlanmamış Yüksek Lisans Tezi)," Marmara Üniversitesi Eğitim Bilimler Enstitüsü, İstanbul, 2012.

[25] D. Osher, et al., "How can we improve school discipline?" Educational Researcher, vol. 39, no. 1, pp. 48-58, 2010.

[26] Güleç, S., Bağçeli, P. and Onur, G., "Öğretmen adaylarının sınıf kurallarının belirlenmesi ve uygulanmasına ilişkin görüşleri,” Illkögretim online, vol. 7, no. 2, pp. 333-348, 2008.

[27] Özcan, G., "İlköğretim I.kademede görevli sınıf öğretmenlerinin sınıf disiplinine ilişkin görüşleri, (Yayınlanmış yüksek lisans tezi)," Gazi Üniversitesi Eğitim Bilimleri Enstitüsü, Ankara, 2008.

[28] Kayabaşı, Y. and Cemaloğlu, N., "Öğretmenlerin sınıflarında kullandıkları disiplin modellerinin farklı değişkenler açısından incelenmesi,” Kırşehir Eğitim Fakültesi Dergisi, vol. 8, pp. 149-170,2007.

[29] Gündoğdu, H. "İlköğretim okullarındaki sınıf öğretmenlerinin sınıf disiplinini sağlamada kullandıkları yöntemlerin ögrenciler üzerindeki etkisi (Yayımlanmamış Yüksek Lisans Tezi),” Beykent Üniversitesi Sosyal Bilimler Enstitüsü, İstanbul, 2007.

[30] Esen, H., "İlk ve ortaöğretim okullarında görev yapan öğretmenlerin kullandıkları disiplin türleri (Edirne İli Örneği) (Yayımlanmamış Yüksek Lisans Tezi)," Trakya Üniversitesi Sosyal Bilimler Enstitüsü, Edirne, 2006.

[31] Sarpkaya, P., "Resmi liselerde disiplin sorunları ve ilgili grupların (öğretmen, öğrenci, yönetici, veli) yaklaşımları (Yayımlanmamış Doktora Tezi),” Dokuz Eylül Üniversitesi Eğitim Bilimleri Enstitüsü, İzmir, 2005.

[32] Lewis, R., "Classroom discipline and student responsibility: The students'view," Teaching and Teacher Education, vol. 17, no. 3, pp. 307-319, 2001.

[33] Giles, R.M., Kazelskis, R., and Reeves-Kazelskis, C., "A factor analysis ofthe discipline efficacy scale," 13th Annual conference of the Mid-South Educational Research Association. Bowling Green, Kentucky, 2000.

[34] Tavşancıl, E., Tutumların ölçülmesi ve SPSS ile veri analizi. Ankara: Nobel Yayın Dağıtım, 2009.

[35] Tezbaşaran, A., Likert tipi ölçek geliştirme kılavuzu, (2 baskı). Ankara, Türk Psikologlar Derneği Yayını, 1997.

[36] DeVellis, R. F., Scale Development Theory and Applications, (2th ed.). SAGE Publications International Educational and Professional Publisher, chapter 5, pp. 60-96, 2003.

[37] Taşkın, C.. and Akat, Ö., Araştırma yöntemlerinde yapısal eșitlik modelleme. Bursa, Ekin Yayınevi, 2010.

[38] Büyüköztürk Ş., "Faktör analizi: temel kavramlar ve ölçek geliştirmede kullanımı," Kuram ve Uygulamada Eğitim Yönetimi Dergisi, vol. 32, pp. 470-83, 2002.

[39] Kurnaz, M., and Yiğit, N., "Fizik Tutum Ölçeği: Geliştirilmesi," Necatibey Eğitim Fakültesi Elektronik Fen ve Matematik Ĕ̈itimi Dergisi, vol. 4, no. 1, pp. 29-49, 2010.

[40] Çokluk, Ö., Şekercioğlu, G., and Büyüköztürk, Ş., Sosyal bilimler için çok değişkenli istatistik. SPSS ve LiSREL uygulamaları. Ankara, Pegem Yayınevi, 2014.

[41] Thompson, B., Exploratory and confirmatory factor analysis: Understanding concepts and applications. Washington DC: American Psychological Association, 2004.

[42] Costello, A. B. ve Osborne, J. W., "Best practices in exploratory factor analysis: Four recommendations for getting the most from your analysis," Practical Assessment Research \& Evaluation, vol. 10, no. 7, pp. 1-9, 2005.

[43] Tabachnick, B. G. and Fidell, L. S., Using multivariate statistics. Boston, Pearson Education, Inc, 2007.

[44] Şencan, H., Sosyal ve davranışsal ölçümlerde güvenirlik ve geçerlilik. Ankara, Seçkin Yayıncılık, 2005.

[45] Jöreskog, K. G., Sörbom, and D. Lisrel, Structural equations modeling with the SIMPLIS command language. Chicago: Scientific Software International, Inc., 1993.

[46] Kline, R.B., Principles and practice of structural equation modeling, (2. ed.). NY: The Guillford Press, 2005.

[47] Sümer, N., "Yapısal eşitlik modelleri: Temel kavramlar ve örnek uygulamalar," Türk Psikoloji Yazıları, vol. 3, no. 6, pp. 74-79, 2000.

[48] Hooper, D., Caughlan, J. and Mullen, M.R., "Structural equation modeling: guidelines for determining model fit," Electronic journal of business research methods, vol, 6, no. 1, pp. 53-60, 2008.

[49] Akgül, A and Çevik, O., Istatistiksel analiz teknikleri. Ankara, Emek Offset, 2003. 